\title{
FORECASTING TOURISM DEMAND IN CROATIA USING BOX AND JENKINS METHODOLOGY
}

\author{
Damira Đukec
}

https://doi.org/10.20867/tosee.05.18

\begin{abstract}
Tourism is a significant sector in Croatian economy, generating income and employment. Recent data show that contribution of tourism to GDP is almost $20 \%$. Planning and forecasting is crucial for further development. Demand forecasting models are therefore essential input in developing a competitive tourism industry which enables sustainable growth. Tourism demand forecasting methods can be divided in qualitative and quantitative methods. Econometric models differ from time series in identifying the casual relationships between variables. Time series models mostly rely on Box and Jenkins autoregressive integrated moving average (ARIMA) or seasonal ARIMA (SARIMA) methodology. For the purpose of this paper we will focus on quantitative methods. Quantitative methods used for forecasting purposes are either time series models or econometric studies. In this paper tourism demand for Croatia has been modelled using Box and Jenkins seasonal ARIMA methodology. The Box-Jenkins methodology refers to a set of procedures for identifying and estimating time series models within the class of autoregressive integrated moving average (ARIMA) models. The data for tourist arrivals showed clear patterns of seasonality and an upward trend. After differentiation and seasonal adjustment, a model selection and diagnostic checking followed. The model selected was seasonal ARIMA $(2,1,1)(0,1,1)_{12}$. The model fits the observed data well and shows no autocorrelation of the residuals.
\end{abstract}

Keywords Tourism demand, Croatia, forecasting, Box and Jenkins, ARIMA

\section{INTRODUCTION}

Tourism is a significant sector in Croatian economy, generating income and employment. Recent data show that contribution of tourism to GDP is almost $20 \%$. Planning and forecasting is crucial for further development. Demand forecasting models are therefore essential input in developing a competitive tourism industry which enables sustainable growth. In this paper a forecasting model will be created for tourism demand in Croatia, using Box and Jenkins methodology. The model will enable more accurate forecasts of tourism demand which will lead to improvement in strategic planning.

Tourism demand forecasting methods can be divided in qualitative and quantitative methods. For the purpose of this paper we will focus on quantitative methods. Quantitative methods used for forecasting purposes are either time series models or econometric studies. The methodologies applied in both of these categories of models, will be further explored discussing their strengths and weaknesses. Econometric models differ from time series in identifying the casual relationships between variables. Time series models mostly rely on Box and Jenkins autoregressive integrated moving average (ARIMA) or seasonal ARIMA (SARIMA) methodology. Generalised Autoregressive 
ToSEE - Tourism in Southern and Eastern Europe, Vol. 5, pp. 263-273, 2019

D. Đukec: FORECASTING TOURISM DEMAND IN CROATIA USING BOX AND JENKINS ...

Conditional Heteroscedastic $(\mathrm{GARCH})$ models are also used as an extension of univariate time series analysis. Econometric models use explanatory variables such as tourist income, tourism prices in a destination relative to origin country, tourism prices of competing destinations and exchange rates to model and predict tourism demand. Some of the techniques applied are regression analysis based on ordinary least squares (OLS), error correction models (ECM), vector autoregressive models (VAR), time varying parameter (TVP), structural equation modelling (SEM), autoregressive distributed lagged model (ADLM) and the almost ideal demand system (AIDS). Other than above mentioned methods, recent developments include empirical applications of artificial intelligence (AI) such as artificial neural network method (ANN), the fuzzy time series method and genetic algorithms (GAs).

This paper consists of five chapters. After introduction there is a short review of recent literature in the field of tourism demand forecasting. In the third chapter theoretical background of the forecasting methodology in this paper is described. Results of the tourism demand forecasting modelling are presented in the fourth chapter. The paper ends with a conclusion where the main results of the research are summarised.

\section{LITERATURE REVIEW}

Tourism demand forecasting is an area of interest for many researchers. In the table below there is only a fraction of papers in the subject that indicate versatility of research methods and applications. There are few examples of modelling tourism demand in Croatia but none of them using Box and Jenkins methodology for modelling total (both domestic and foreign tourist arrivals as a measure of demand) tourism demand. A thorough review of literature undertaken by Song and Li (2008) confirms the conclusion of earlier research that there is no evidence of one model consistently outperforming other models. Some recent developments in the field include the use of AI techniques and the use of forecast combination and forecast integration of quantitative and qualitative approaches which leads to improvement in forecast accuracy.

Table 1: Recent empirical applications

\begin{tabular}{|l|l|l|}
\hline Author & Methodology & Country \\
\hline Petrevska (2017) & ARIMA & Macedonia \\
\hline Tica and Kožić (2015) & Leading indicator & Croatia \\
\hline $\begin{array}{l}\text { Cerović, Grudić Kvasić and } \\
\text { Ivančić (2017) }\end{array}$ & Exponential smoothing & Croatia \\
\hline Song and Witt (2006) & VAR & Macau \\
\hline $\begin{array}{l}\text { Chhorn and Chaiboonsri } \\
(2017)\end{array}$ & GARCH & Cambodia \\
\hline Lee (2010) & ECM & Hong Kong \\
\hline $\begin{array}{l}\text { Song, Li, Witt and } \\
\text { Athanasopoulos (2011) }\end{array}$ & TVP & Hong Kong \\
\hline Baldigara and Koić (2015) & OLS & Croatia \\
\hline Constantino et al. (2016) & ANN & Mozambique \\
\hline Turner and Witt (2001) & SEM & New Zeland \\
\hline Han et al. (2006) & AIDS & Europe \\
\hline
\end{tabular}


ToSEE - Tourism in Southern and Eastern Europe, Vol. 5, pp. 263-273, 2019

D. Đukec: FORECASTING TOURISM DEMAND IN CROATIA USING BOX AND JENKINS ...

\begin{tabular}{|l|l|l|}
\hline Author & Methodology & Country \\
\hline Song et al. (2003) & ADLM & Hong Kong \\
\hline Sakhuja et al. (2016) & GA Fuzzy Time Series & Taiwan \\
\hline Singh (2013) & SARIMA & Bhutan \\
\hline
\end{tabular}

Source: author

\section{THEORETICAL BACKGROUND}

In this paper tourism demand for Croatia will be modelled and forecasted using Box and Jenkins methodology. The Box-Jenkins methodology refers to a set of procedures for identifying and estimating time series models within the class of autoregressive integrated moving average (ARIMA) models. The Box-Jenkins method refers to the iterative application of the following three steps: 1. Identification. Using plots of the data, autocorrelations, partial autocorrelations, and other information, a class of simple ARIMA models is selected. This amounts to estimating appropriate values for $\mathrm{p}^{1}, \mathrm{~d}^{2}$, and $q^{3} .2$. Estimation. The phis and thetas of the selected model are estimated using maximum likelihood techniques, backcasting, etc., as outlined in Box-Jenkins (1976). 3. Diagnostic Checking. The fitted model is checked for inadequacies by considering the autocorrelations of the residual series. Monthly data on tourist arrivals, domestic and total, were used as a measure for tourism demand. The data showed a clear seasonal pattern so a seasonal ARIMA was used for modelling.

To deal with series containing seasonal fluctuations, Box-Jenkins recommend the following general model:

$\phi_{\mathrm{p}}(\mathrm{B}) \varphi_{\mathrm{P}}\left(\mathrm{B}^{\mathrm{s}}\right)(1-\mathrm{B})^{\mathrm{d}}\left(1-\mathrm{B}^{\mathrm{s}}\right)^{\mathrm{D}} \mathrm{Y}_{\mathrm{t}}=\theta_{\mathrm{q}}(\mathrm{B}) \Theta_{\mathrm{Q}}\left(\mathrm{B}^{\mathrm{s}}\right) \varepsilon_{\mathrm{t}}$

where $\mathrm{d}$ is the order of differencing, $\mathrm{s}$ is the number of seasons per year, and D is the order of seasonal differencing. The operator polynomials are

$$
\begin{aligned}
& \phi_{\mathrm{p}}(\mathrm{B})=\left(1-\phi_{1} \mathrm{~B}-\cdots \cdot \phi_{\mathrm{p}} \mathrm{B}^{\mathrm{p}}\right) \\
& \theta_{\mathrm{q}}(\mathrm{B})=\left(1-\theta_{1} \mathrm{~B}-\cdots \cdot-\theta_{\mathrm{q}} \mathrm{B}^{\mathrm{q}}\right) \\
& \varphi_{\mathrm{P}}\left(\mathrm{B}^{\mathrm{s}}\right)=\left(1-\varphi_{1} \mathrm{~B}-\cdots \cdots-\varphi_{\mathrm{P}} \mathrm{B}^{\mathrm{sP}}\right) \\
& \Theta_{\mathrm{Q}}\left(\mathrm{B}^{\mathrm{s}}\right)=\left(1-\Theta_{1} \mathrm{~B}-\cdots \cdot-\Theta_{\mathrm{Q}} \mathrm{B}^{\mathrm{sQ}}\right)
\end{aligned}
$$

Note that $\left(1-B^{s}\right) Y_{t}=Y_{t}-Y_{t-s}$.

Box-Jenkins explain that the maximum value of d, D, p, q, P, and Q is two. Hence, these operator polynomials are usually simple expressions.

\footnotetext{
${ }^{1} \mathrm{P}$ is the order of the autoregressive process i.e. the number of AR terms

${ }^{2} \mathrm{~d}$ shows the number of times the series has to be differenced before it becomes stationary

${ }^{3} \mathrm{q}$ is the order of the moving average process i.e. the number of MA terms
} 
ToSEE - Tourism in Southern and Eastern Europe, Vol. 5, pp. 263-273, 2019

D. Đukec: FORECASTING TOURISM DEMAND IN CROATIA USING BOX AND JENKINS ...

\section{EMPIRICAL RESULTS}

In this section the results of the empirical research will be presented. To find a forecasting model for Croatian tourism demand Box and Jenkins approach was used. The data used in this research are monthly tourist arrivals for period from January 2010 to September 2018 and are downloaded from the web site of Croatian Bureau of Statistics. The observed time period makes 105 observations which is considered to be a large sample for seasonal forecasting (Hyndman and Kostenko, 2007). As we can see from figure 1. The data show a clear seasonal pattern with a growth trend. Also, we can detect a presence of heteroscedasticity in the data.

\section{Figure 1: Monthly tourist arrivals to Croatia}

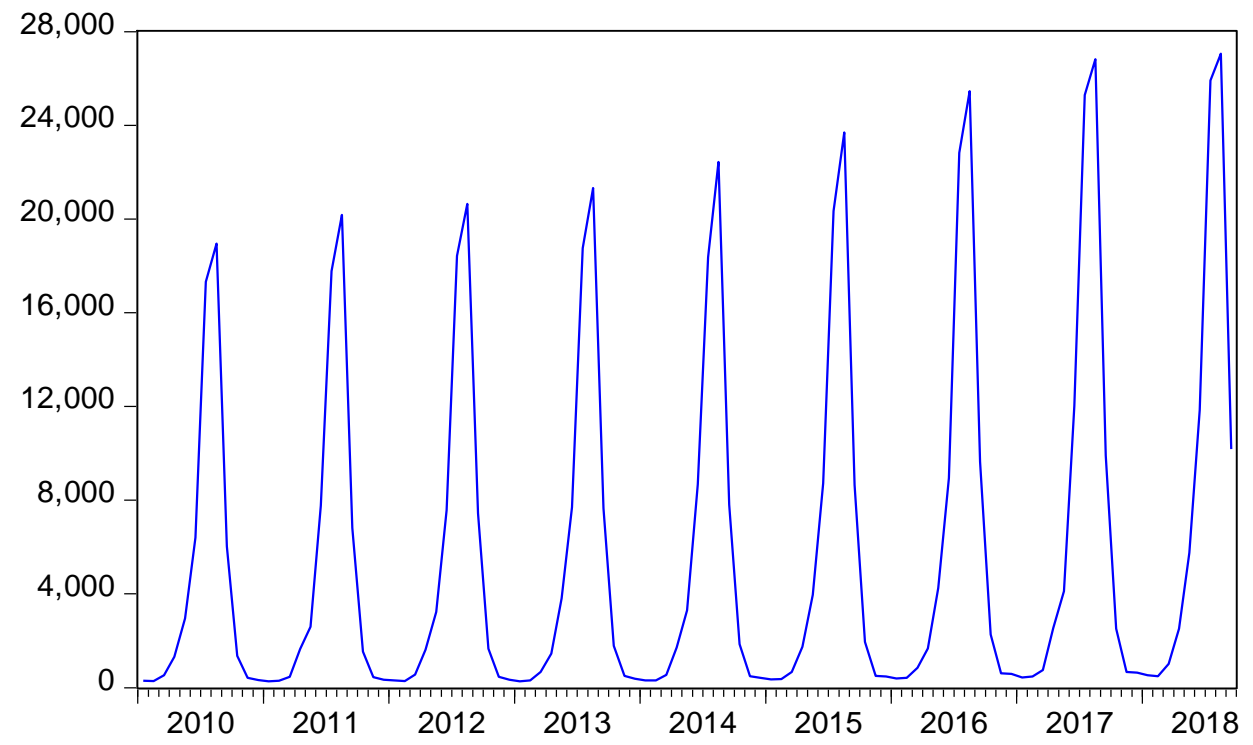

Source: output of statistical software EViews 9

Further modelling requires transformation of the data described above. To remove the growth trend and seasonality the data has been differenced. Also, a log transformation of the data has been made to remove the heteroscedasticity. After transformation the data (figure 2) appears to be stationary. To test the stationarity Augmented Dickey Fuller test has been applied (table 2). 
ToSEE - Tourism in Southern and Eastern Europe, Vol. 5, pp. 263-273, 2019

D. Đukec: FORECASTING TOURISM DEMAND IN CROATIA USING BOX AND JENKINS ...

Figure 2: Monthly tourist arrivals to Croatia - transformed data

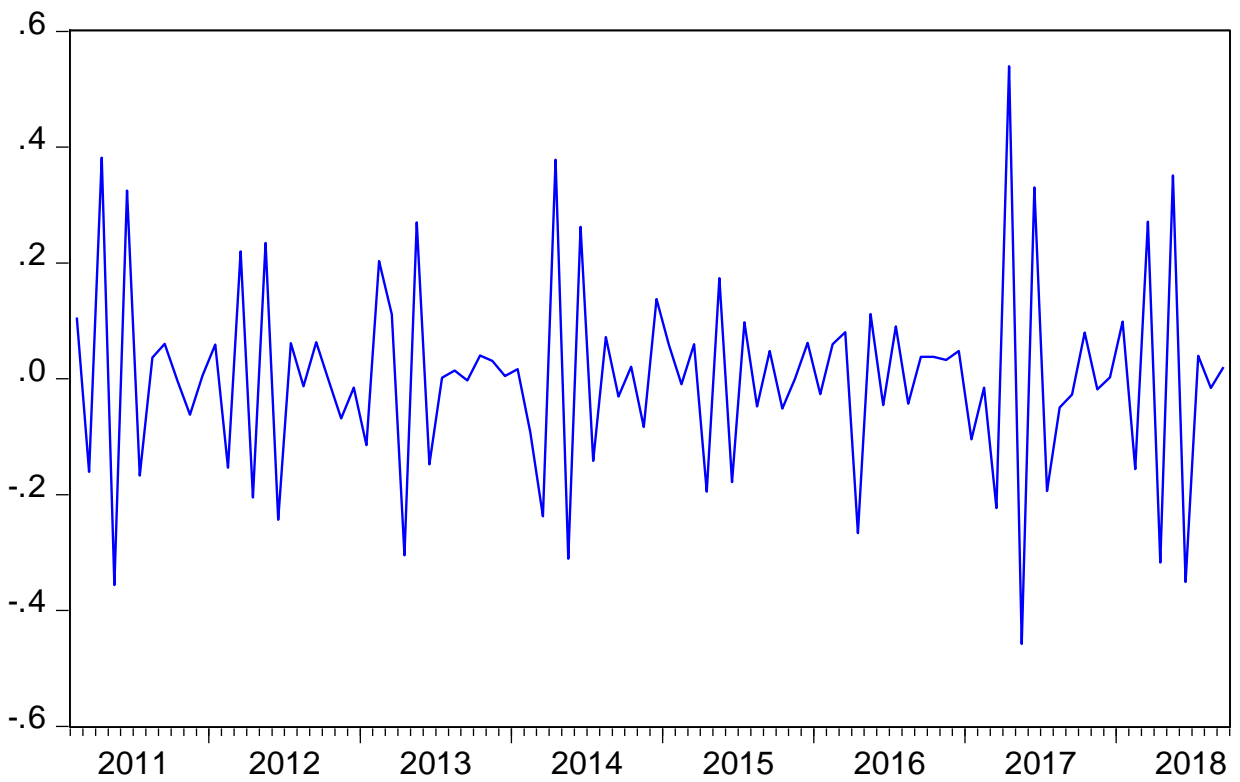

Source: output of statistical software EViews 9

The results of the ADF test are shown in the table below. The null hypothesis is that transformed data have a unit root, which would imply that the data is nonstationary. With the probability of 0,0000 the null hypothesis is rejected leading to aa conclusion that the data are stationary. After achieving stationarity, the next step in the modelling process is to select a model.

Table 2: Augmented Dickey-Fuller test

Null Hypothesis: DTOTAL1 has a unit root Exogenous: None

Lag Length: 1 (Automatic - based on SIC, maxlag=11)

\begin{tabular}{lccc}
\hline \hline & t-Statistic & Prob. ${ }^{*}$ \\
\hline \hline Augmented Dickey-Fuller test statistic & -12.25502 & 0.0000 \\
\hline Test critical values: & 1\% level & -2.590910 & \\
& 5\% level & -1.944445 & \\
& $10 \%$ level & -1.614392 & \\
\hline \hline
\end{tabular}

*MacKinnon (1996) one-sided p-values. 
ToSEE - Tourism in Southern and Eastern Europe, Vol. 5, pp. 263-273, 2019

D. Đukec: FORECASTING TOURISM DEMAND IN CROATIA USING BOX AND JENKINS ...

Augmented Dickey-Fuller Test Equation

Dependent Variable: D(DTOTAL1)

Method: Least Squares

Date: 01/24/19 Time: 14:04

Sample (adjusted): 2011M04 2018M09

Included observations: 90 after adjustments

\begin{tabular}{lllll}
\hline \hline Variable & Coefficient & Std. Error & t-Statistic & Prob. \\
\hline \hline DTOTAL1(-1) & -2.341398 & 0.191056 & -12.25502 & 0.0000 \\
D(DTOTAL1(-1)) & 0.309198 & 0.100837 & 3.066300 & 0.0029 \\
\hline \hline R-squared & 0.905851 & Mean dependent var & 0.002010 \\
Adjusted R-squared & 0.904781 & S.D. dependent var & 0.333875 \\
S.E. of regression & 0.103026 & Akaike info criterion & -1.685699 \\
Sum squared resid & 0.934064 & Schwarz criterion & -1.630148 \\
Log likelihood & 77.85645 & Hannan-Quinn criter. & -1.663297 \\
Durbin-Watson stat & 1.946123 & & \\
\hline \hline
\end{tabular}

Source: output of statistical software EViews 9

The model selection starts with the detail examination of autocorrelogram and partial autocorrelogram of the data. As we can see both ACF and PACF slowly decay after first few significant spikes which indicates a possible mixed model with both AR and MA processes present. Also we detect significant spikes around lag 12 in ACF implying seasonal MA process.

Figure 3: ACF and PACF

Date: 01/24/19 Time: 13:59

Sample: 2010M01 2019M09

Included observations: 92

\begin{tabular}{|c|c|c|c|c|c|c|}
\hline Autocorrelation & Partial Correlation & & $\mathrm{AC}$ & PAC & Q-Stat & Prob \\
\hline$* * * * * *|. \quad|$ & $* * * * * *||$. & 1 & -0.790 & -0.790 & 59.293 & 0.000 \\
\hline.$|* * * *|$ & $* * \mid$ & 2 & 0.506 & -0.314 & 83.891 & 0.000 \\
\hline$* *|\quad|$ & .1. & 3 & -0.299 & -0.065 & 92.599 & 0.000 \\
\hline$\left.\cdot\right|^{*}$ &.$*$ & 4 & 0.114 & -0.183 & 93.869 & 0.000 \\
\hline .1. & $* * \mid$. & 5 & -0.044 & -0.219 & 94.065 & 0.000 \\
\hline 1. & $* *$ & 6 & 0.021 & -0.128 & 94.108 & 0.000 \\
\hline$\cdot \mid$ &. $\mid$ & 7 & 0.041 & 0.073 & 94.276 & 0.000 \\
\hline$*$. & $*$. & 8 & -0.123 & -0.152 & 95.830 & 0.000 \\
\hline.$|* *|$ &. & 9 & 0.216 & 0.070 & 100.69 & 0.000 \\
\hline$* *$ &.$*$ & 10 & -0.316 & -0.153 & 111.20 & 0.000 \\
\hline.$|* * *|$ &.$\left.\right|^{*}$ & 11 & 0.417 & 0.192 & 129.76 & 0.000 \\
\hline$* * *||$. &. $\mid$ & 12 & -0.465 & -0.052 & 153.17 & 0.000 \\
\hline.$|* * *|$ &.$*$ & 13 & 0.379 & -0.195 & 168.86 & 0.000 \\
\hline$* *|. \quad|$ &.$|1|$ & 14 & -0.220 & 0.063 & 174.24 & 0.000 \\
\hline
\end{tabular}


ToSEE - Tourism in Southern and Eastern Europe, Vol. 5, pp. 263-273, 2019

D. Đukec: FORECASTING TOURISM DEMAND IN CROATIA USING BOX AND JENKINS ...

Date: 01/24/19 Time: 13:59

Sample: 2010M01 2019M09

Included observations: 92

\begin{tabular}{|c|c|c|c|c|c|c|}
\hline Autocorrelation & Partial Correlation & & $\mathrm{AC}$ & PAC & Q-Stat & Prob \\
\hline.$\left.\right|^{*}$ & 7. & 15 & 0.089 & 0.036 & 175.13 & 0.000 \\
\hline. $\mid$ &.$*$ & 16 & -0.025 & -0.120 & 175.20 & 0.000 \\
\hline.$|. \quad|$ &. & 17 & 0.027 & 0.011 & 175.28 & 0.000 \\
\hline $.1 . \quad 1$ &. $\mid$ & 18 & -0.029 & 0.064 & 175.38 & 0.000 \\
\hline $.1 . \quad \mid$ &. $\mid$ & 19 & 0.003 & 0.036 & 175.38 & 0.000 \\
\hline. &.$*$ & 20 & 0.004 & -0.191 & 175.38 & 0.000 \\
\hline. $\mid$ &. $\mid * *$ & 21 & 0.033 & 0.216 & 175.51 & 0.000 \\
\hline.$* 1$ & $* * \mid$ & 22 & -0.110 & -0.215 & 177.01 & 0.000 \\
\hline$.\left.\right|^{*} \quad \mid$ &.$\left.\right|^{* *}$ & 23 & 0.206 & 0.222 & 182.34 & 0.000 \\
\hline$* *|. \quad|$ &.$*$ & 24 & -0.252 & -0.094 & 190.44 & 0.000 \\
\hline$.\left.\right|^{*} \quad \mid$ &.$*$ & 25 & 0.205 & -0.160 & 195.84 & 0.000 \\
\hline$. * \mid$ &. $\mid$ & 26 & -0.151 & -0.015 & 198.85 & 0.000 \\
\hline$.\left.\right|^{*} \mid$ &. & 27 & 0.122 & 0.045 & 200.84 & 0.000 \\
\hline $.1 . \quad 1$ &.$\left.\right|^{*}$ & 28 & -0.046 & 0.091 & 201.13 & 0.000 \\
\hline .1 &. & 29 & -0.002 & 0.072 & 201.13 & 0.000 \\
\hline. $\mid$ &. & 30 & 0.010 & -0.021 & 201.14 & 0.000 \\
\hline .1 & .1 & 31 & -0.037 & 0.054 & 201.33 & 0.000 \\
\hline. &.$*$ & 32 & 0.066 & -0.079 & 201.95 & 0.000 \\
\hline$. * \mid$ &.$*$ & 33 & -0.166 & -0.113 & 205.98 & 0.000 \\
\hline.$|* *|$ &.$*$ & 34 & 0.311 & -0.097 & 220.40 & 0.000 \\
\hline$* * *|\quad|$ &.$*$ & 35 & -0.441 & -0.079 & 249.87 & 0.000 \\
\hline.$|* * * *|$ &.$|. \quad|$ & 36 & 0.509 & 0.044 & 289.90 & 0.000 \\
\hline
\end{tabular}

Source: output of statistical software EViews 9

Based on the initial analysis of ACF and PACF several models, following parsimony principle, have been estimated and evaluated. Finally, a model was selected based on the lowest Akaike information criterion. The selected model is seasonal ARIMA $(2,1,1)$ $(0,1,1)_{12}$ can be written in its general form as follows:

$\left(1-\phi_{2} \mathrm{~B}\right)(1-\mathrm{B})\left(1-\mathrm{B}^{12}\right) \mathrm{Y}_{\mathrm{t}}=\left(1-\theta_{1} \mathrm{~B}\right)\left(1-\Theta_{1} \mathrm{~B}^{12}\right) \varepsilon_{\mathrm{t}}$

where, $\mathrm{Y}_{\mathrm{t}}$ represents tourist arrivals, $\mathrm{B}$ is the backshift operator, and $\varepsilon_{\mathrm{t}}$ is white noise. Estimation results of the model (1) are shown in the table 3. 
ToSEE - Tourism in Southern and Eastern Europe, Vol. 5, pp. 263-273, 2019

D. Đukec: FORECASTING TOURISM DEMAND IN CROATIA USING BOX AND JENKINS ...

Table 3: Model estimation results

Dependent Variable: DLOG(TOTAL,1,12)

Method: ARMA Maximum Likelihood (OPG - BHHH)

Date: 01/24/19 Time: 13:39

Sample: 2011M02 2018M09

Included observations: 92

Convergence achieved after 22 iterations

Coefficient covariance computed using outer product of gradients

\begin{tabular}{|c|c|c|c|c|}
\hline Variable & Coefficient & Std. Error & t-Statistic & Prob. \\
\hline $\mathrm{AR}(2)$ & 0.381253 & 0.114422 & 3.331989 & 0.0013 \\
\hline MA(1) & -0.928624 & 0.050090 & -18.53920 & 0.0000 \\
\hline $\operatorname{SMA}(12)$ & -0.593661 & 0.099687 & -5.955232 & 0.0000 \\
\hline SIGMASQ & 0.007179 & 0.001100 & 6.526947 & 0.0000 \\
\hline R-squared & 0.763653 & \multirow{6}{*}{\multicolumn{2}{|c|}{$\begin{array}{l}\text { Mean dependent var } \\
\text { S.D. dependent var } \\
\text { Akaike info criterion } \\
\text { Schwarz criterion } \\
\text { Hannan-Quinn criter. }\end{array}$}} & 0.001418 \\
\hline Adjusted R-squared & 0.755595 & & & 0.175238 \\
\hline S.E. of regression & 0.086633 & & & -1.932817 \\
\hline Sum squared resid & 0.660460 & & & -1.823174 \\
\hline Log likelihood & 92.90958 & & & -1.888564 \\
\hline Durbin-Watson stat & 2.140627 & & & \\
\hline Inverted AR Roots & .62 & -.62 & & \\
\hline \multirow[t]{4}{*}{ Inverted MA Roots } & .96 & .93 & $.83-.48 \mathrm{i}$ & $.83+.48 \mathrm{i}$ \\
\hline & $.48+.83 \mathrm{i}$ & $.48-.83 \mathrm{i}$ & $.00-.96 \mathrm{i}$ & $-.00+.96 \mathrm{i}$ \\
\hline & $-.48+.83 i$ & $-.48-.83 \mathrm{i}$ & $-.83+.48 \mathrm{i}$ & $-.83-.48 \mathrm{i}$ \\
\hline & -.96 & & & \\
\hline
\end{tabular}

Source: output of statistical software EViews 9

The estimated seasonal ARIMA model can be written as follows:

$\left(1-0,381253_{2} \mathrm{~B}\right)(1-\mathrm{B})\left(1-\mathrm{B}^{12}\right) \mathrm{Y}_{\mathrm{t}}=\left(1+0,928624{ }_{1} \mathrm{~B}\right)\left(1+0,593661_{1} \mathrm{~B}^{12}\right) \varepsilon_{\mathrm{t}}$

All the estimated coefficients are significant and $\mathrm{R}^{2}$ is 0,76 which indicates that the model fits the data well. Further analysis of the estimated model requires diagnostic checking of the residuals. The ACF and PACF figure below shows no indication of autocorrelation in the residuals. 
ToSEE - Tourism in Southern and Eastern Europe, Vol. 5, pp. 263-273, 2019

D. Đukec: FORECASTING TOURISM DEMAND IN CROATIA USING BOX AND JENKINS ...

Figure 4: ACF and PACF of residuals

Date: 01/24/19 Time: 14:14

Sample: 2010M01 2018M09

Included observations: 92

Q-statistic probabilities adjusted for 3 ARMA terms

\begin{tabular}{|c|c|c|c|c|c|c|}
\hline Autocorrelation & Partial Correlation & & $\mathrm{AC}$ & PAC & Q-Stat & Prob \\
\hline$. * \mid$ & $* *$ & 1 & -0.110 & -0.110 & 1.1520 & \\
\hline. $\mid$ & .1 & 2 & 0.011 & -0.002 & 1.1628 & \\
\hline . $* 1$ & $*$. & 3 & -0.068 & -0.068 & 1.6141 & \\
\hline .*. | & $* *$ & 4 & -0.163 & -0.181 & 4.2267 & 0.040 \\
\hline .1. & .1. & 5 & 0.023 & -0.018 & 4.2788 & 0.118 \\
\hline.$\left.\right|^{*}$ &.$\left.\right|^{*}$ & 6 & 0.077 & 0.076 & 4.8790 & 0.181 \\
\hline .1. & *.. & 7 & -0.059 & -0.071 & 5.2349 & 0.264 \\
\hline.$*$. & $* *$ & 8 & -0.120 & -0.175 & 6.7192 & 0.242 \\
\hline .1 & .1. & 9 & 0.010 & -0.011 & 6.7298 & 0.347 \\
\hline *. & *. & 10 & -0.107 & -0.096 & 7.9410 & 0.338 \\
\hline.$\left.\right|^{*}$ &.$\left.\right|^{*}$ & 11 & 0.193 & 0.128 & 11.901 & 0.156 \\
\hline .1. & .1. & 12 & -0.022 & -0.044 & 11.953 & 0.216 \\
\hline$\left.\right|^{*}$ &.$\left.\right|^{*}$ & 13 & 0.168 & 0.171 & 15.044 & 0.130 \\
\hline. &. & 14 & -0.046 & -0.005 & 15.280 & 0.170 \\
\hline .1. & .1. & 15 & -0.018 & 0.017 & 15.317 & 0.225 \\
\hline .1. & $\left.\right|^{*}$ & 16 & 0.063 & 0.079 & 15.763 & 0.262 \\
\hline. $\mid$ & .1. & 17 & -0.005 & 0.043 & 15.765 & 0.328 \\
\hline .*. & *. & 18 & -0.070 & -0.088 & 16.330 & 0.360 \\
\hline.$* 1$. & $*$. & 19 & -0.077 & -0.075 & 17.031 & 0.384 \\
\hline .1. & .1. & 20 & -0.039 & -0.022 & 17.209 & 0.440 \\
\hline .1. & .1. & 21 & -0.057 & -0.003 & 17.605 & 0.482 \\
\hline .1. & **. & 22 & -0.006 & -0.122 & 17.609 & 0.549 \\
\hline$\left.\right|^{*}$ &.$\left.\right|^{*}$ & 23 & 0.096 & 0.113 & 18.774 & 0.537 \\
\hline .*. & *. & 24 & -0.143 & -0.201 & 21.367 & 0.437 \\
\hline .1. & .1. & 25 & 0.033 & 0.004 & 21.508 & 0.490 \\
\hline .1. & .1. & 26 & 0.012 & -0.059 & 21.528 & 0.549 \\
\hline $.1^{*}$ & $.1^{*}$ & 27 & 0.133 & 0.166 & 23.871 & 0.469 \\
\hline .1. & .1. & 28 & 0.072 & 0.007 & 24.577 & 0.486 \\
\hline . & *. & 29 & -0.087 & -0.119 & 25.614 & 0.484 \\
\hline .*. & $*$ & 30 & -0.110 & -0.096 & 27.297 & 0.448 \\
\hline . &. $\mid$ & 31 & -0.086 & -0.005 & 28.349 & 0.446 \\
\hline.$* 1$. & *. & 32 & -0.099 & -0.190 & 29.775 & 0.425 \\
\hline. $\mid$ & .1. & 33 & 0.003 & -0.037 & 29.776 & 0.477 \\
\hline$\left.\right|^{*}$ & .1. & 34 & 0.088 & -0.014 & 30.923 & 0.470 \\
\hline.$* 1$ &.$|\quad|$ & 35 & -0.148 & -0.036 & 34.255 & 0.360 \\
\hline$\left.\right|^{* *} \mid$ & $.\left.\right|^{*} \mid$ & 36 & 0.231 & 0.128 & 42.461 & 0.125 \\
\hline
\end{tabular}

Source: output of statistical software EViews 9 
ToSEE - Tourism in Southern and Eastern Europe, Vol. 5, pp. 263-273, 2019

D. Đukec: FORECASTING TOURISM DEMAND IN CROATIA USING BOX AND JENKINS ...

Figure 5. shows actual vs. fitted values and residuals. As we can see from the figure the model fits quite well to the actual values. The pattern of the residuals seems to confirm the model to be adequate.

Figure 5: Monthly tourist arrivals to Croatia - actual, fitted and residual

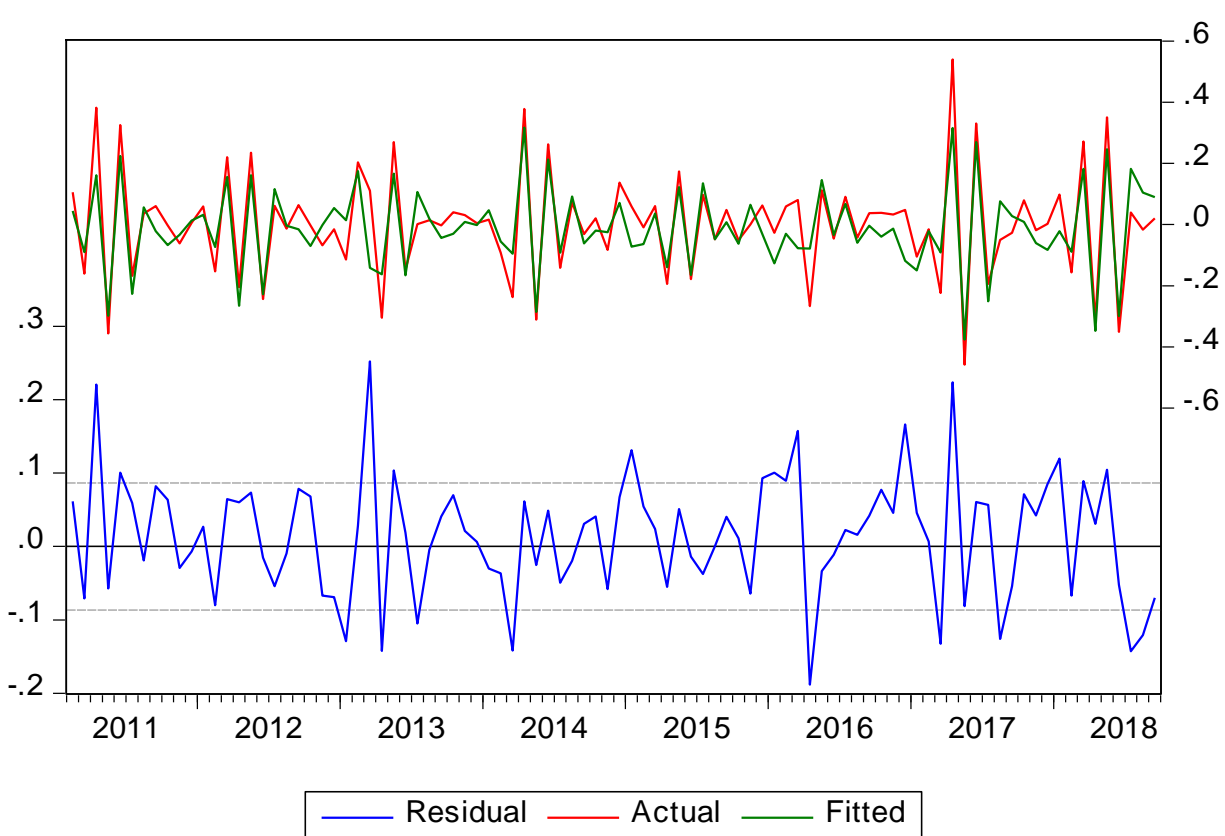

Source: output of statistical software EViews 9

\section{CONCLUSION}

Tourism is an important sector of Croatian economy, generating fifth of its GDP. For the purpose of tourism development, it is very important to have quality research in the field as an input for strategic planning. One of the most fundamental need for further development of tourism is demand forecasting. This paper aimed to give its contribution to answering that specific need. Tourism demand forecasting methods can be divided in qualitative and quantitative methods. Quantitative methods used for forecasting purposes are either time series models or econometric studies. In this paper tourism demand for Croatia has been modelled using Box and Jenkins seasonal ARIMA methodology. The Box-Jenkins methodology refers to a set of procedures for identifying and estimating time series models within the class of autoregressive integrated moving average (ARIMA) models. The data for tourist arrivals showed clear patterns of seasonality and an upward trend. After differentiation and seasonal adjustment, a model selection and diagnostic checking followed. The model selected was seasonal ARIMA $(2,1,1)$ $(0,1,1)_{12}$. The model fits the observed data well and shows no autocorrelation of the residuals. The value of the model developed in this paper is in its practical implications for tourism demand forecasting. The information provided from econometric models can 
ToSEE - Tourism in Southern and Eastern Europe, Vol. 5, pp. 263-273, 2019

D. Đukec: FORECASTING TOURISM DEMAND IN CROATIA USING BOX AND JENKINS ...

be of great value for decision makers such as local government, tourist boards, tourism ministry and tourism companies. Future research should aim in developing models using other methodologies mentioned in this paper. Comparative analysis of their performance is also recommended.

\section{REFERENCES}

Baldigara, T. and Koić, M., (2015), "Modelling the international tourism demand in Croatia using a polynominal regression analysis", Turističko poslovanje, No. 15, pp. 29-38.

Biljana, P., (2017), "Forecasting international tourism demand: the evidence from Macedonia", UTMS Journal of economics, Vol. 3, No. 1, pp. 45-55.

Box, G.E.P and Jenkins, G.M. (1976), Time series analysis: forecasting and control, San Francisco, Holden Day.

Cerović, Z., Grudić Kvasić, S. and Ivančić, I. (2017), Forecasting tourism demand - the case of the city of Rijeka, DIEM, Vol. 3, No. 1, pp. 750-763.

Chhorn, T. and Chaiboonsri, C. (2018), "Modelling and Forecasting Tourist Arrivals to Cambodia: An Application of ARIMA - GARCH Approach”, Journal of Management, Economics, and Industrial Organization, Vol. 2, No. 2, pp.1-19.

Constantino et al. (2016), "Tourism demand modelling and forecasting with artificial neural network models: The Mozambique case study", Tekhne, Vol. 14, No. 2, pp. 113-124, https://doi.org/10.1016/j.tekhne.2016.04.006

Han, Z., Durbarry, R., and Sinclair, M. T. (2006), "Modelling US tourism demand for European Hong Kong tourism”, International Journal of Hospitality Management, Vol. 22, pp. 435-451.

Hyndman, R.J. and Kostenko, A.V. (2007), "Minimum sample size requirements for seasonal forecasting models", Forsight, 6, pp. 12-15.

Lee, K.N. (2010), "Forecasting long - haul tourism demand using error correction model", Applied Economics, Vol. 43, No. 5, pp. 527-549

Sakhuja, S., Jain, V., Kumar, S., Chandra, C., Ghildayal, S.K. (2016), "Genetic algorithm based fuzzy time series tourism demand forecast model”, Industrial Management \& Data Systems, Vol. 116, Issue 3 , pp. 483-507, https://doi.org/10.1108/IMDS-05-2015-0165

Singh, E.H. (2013), "Forecasting tourist inflow in Bhutan using seasonal ARIMA", IJSR, Vol. 9, No. 2, pp $242-245$.

Song, H. and Li, G. (2008), "Tourism demand modelling and forecasting - A review of recent research", Tourism Research, Vol. 29, No. 2, pp. 203-220,

Song, H. and Witt, S.F. (2006), "Tourism demand forecasting: a time varying parameter error correction model", Journal of Travel Research, Vol. 45, No. 2, pp. 175-185.

Song, H., Li, G., Witt, S.F. and Athanasopoulos, G. (2011), "Forecasting tourist arrivals using time varying parameter structural time series models", International Journal of Forecasting, Vol. 27, No. 3, pp. 855-869.

Song, H., Wong, K.K.F., and Chon, K.K.S. (2003c), "Modelling and forecasting the demand for destinations", Tourism Management, 27, pp. 1-10.

Tica, J. and Kožić, I. (2015), "Forecasting Croatian inbound tourism demand", Economic Research, Vol. 28 , No. 1, pp. 1046-1062.

Turner, L.W., and Witt, S.F. (2001a), "Factors influencing demand for international tourism: Tourism demand analysis using structural equation modelling, revisited", Tourism Economics, 7, pp. 21-38. www.dzs.hr

Damira Đukec, PhD, Assistant Professor

University North

Department of Business Economy

104. brigade 3, 40000 Varaždin, Croatia

Phone: 0911593575

E-mail: ddukec@unin.hr 